\title{
Nutritional status of tuberculosis patients, a comparative cross-sectional study
}

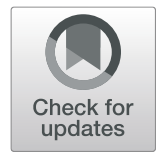

Berhanu Elfu Feleke ${ }^{1^{*}}$, Teferi Elfu Feleke ${ }^{2}$ and Fantahun Biadglegne ${ }^{3}$

\begin{abstract}
Background: Each year, more than 13.7 million people became an active case of tuberculosis and more than 1.5 million cases of TB patient will die. The association between TB and malnutrition is bi-directional, TB leads the patient to malnutrition, and malnutrition increases the risk of developing active TB by 6 to 10 times. Improving the nutrition of individual greatly reduces tuberculosis. The aims of this study were to assess the nutritional status and determinants of underweight among TB patients.

Methods: A comparative cross-sectional study design was implemented. The sample size was calculated using $95 \%$ $\mathrm{Cl}, 90 \%$ power, the prevalence of malnutrition in TB patients 50\%,

TB patients to TB free resident ratio of 3, the design effect of 2 and a $5 \%$ non-response rate. Systematic random sampling was used to select TB patients and simple random sampling technique was used to select TB free residents. The data were collected from July 2015-May 2018. The data were collected by interviewing the patient, measuring anthropometric indicators and collecting the stool and blood samples. The data were entered into the computer using Epi-info software and analyzed using SPSS software. Descriptive statistics were used to find the proportion of malnutrition. Binary logistic regression was used to identify the determinants of malnutrition.

Results: A total of 5045 study participants (1681 TB patients and 3364 TB free residents) were included giving for the response rate of $93.1 \%$. The prevalence of underweight among TB patients was $57.17 \%$ ( $95 \% \mathrm{Cl}$ : 54.80 , $59.54 \%$ ) and $88.52 \%$ of TB patients were anemic. The prevalence of malnutrition (underweight) among TB free residents was $23.37 \%$ (95\% Cl: 21.93-24.80). The nutritional status of TB patients was determined by site of infection AOR: 0.68 [0.49-0.94], sex of the patient AOR: 0.39 [0.25-0.56], residence AOR: 3.84 [2.74-5.54], intestinal parasite infection AOR: 7 [5.2-9.95], problematic alcohol use AOR: 1.52 [1.17-2.13].

Conclusion: High proportions of TB patients were malnourished. TB patients were highly susceptible to malnutrition and even a very distal reason for malnutrition in the community became a proximal cause for TB patients.
\end{abstract}

Keywords: Malnutrition, Tuberculosis, Predictors, Ethiopia

\section{Background}

Underweight is a malnutrition stage in which the body mass index (BMI) of adult scores less than $18.5 \mathrm{KG} / \mathrm{M}^{2}$ cuts-points $[1,2]$. It results from an imbalance between the supply of food and the body demands for the nutrients. Conditions like genetics, metabolism disorders, medication side effects, eating disorders, and tuberculosis predispose to underweight $[3,4]$.

\footnotetext{
* Correspondence: elfufeleke@gmail.com

${ }^{1}$ Department of Epidemiology and Biostatistics, University of Bahir Dar, Bahir Dar, Ethiopia

Full list of author information is available at the end of the article
}

Tuberculosis (TB) is an infectious disease caused by mycobacterium TB species. According to the world health organization (WHO), tuberculosis attacks 10 million people and kills 1.3 million people every year [5]. The association between $\mathrm{TB}$ and malnutrition is bidirectional, TB predisposes the patient to malnutrition and malnutrition increases the risk of developing active TB by 6 to 10 folds [6-11]. One-quarter of TB in the world was as a result of malnutrition, improving the nutritional status of the individual decreases the risk of TB [12]. Additionally, malnutrition increases TB relapse and mortality [13-20].

(C) The Author(s). 2019 Open Access This article is distributed under the terms of the Creative Commons Attribution 4.0 International License (http://creativecommons.org/licenses/by/4.0/), which permits unrestricted use, distribution, and 
The treatment outcomes of TB patients can be improved by studying their nutritional status [13, 20]. Incorporating nutritional support during directly observed treatment strategy (DOTS) increases the probability of favorable treatment outcomes [16, 19, 21-27].

The prevalence of malnutrition in the South American continent range from $20-50 \%[28,29]$, in the Asian continent malnutrition among TB patient ranges from 68.6 - $87 \%[11,20]$ and in the United Kingdom, the body mass index of TB patients was $13 \%$ lower than the general community [18]. On the African continent, $29-61 \%$ of TB patients were malnourished [14, 24, 30-33].

The tuberculosis treatment guideline neglects the nutritional supplementation part of an intervention. Priority was not given by decision-makers as a result of evidence scarcity. This study will generate baseline information to give priority to the nutritional intervention part of $\mathrm{TB}$ treatment.

The objectives of this research were to estimate and compare the proportion of underweight and their determinants among the TB patients in a resource-limited setting.

\section{Methods}

A comparative cross-sectional study design was implemented. This study was conducted in Amhara regional state of Ethiopia. The region contains 25,000,000 population and every year more than 25,000 tuberculosis cases are reported from the health facilities. The target population was TB patients receiving the DOTS in the health centers of the Amhara region. New TB patients diagnosed during the data collection method were included. TB patients not willing to participate during the study and TB patients unable to communicate properly were excluded. The nutritional status of TB patients was compared with TB free residents. The sample size was calculated using Epi-info software version 7 assuming 95\% CI, 90\% power, the proportion of malnutrition in TB patients $50 \%$, TB patients to TB free resident ratio of 3 , the design effect of 2 and a $5 \%$ non-response rate $[6,34]$. Finally, the estimated sample size was $1806 \mathrm{~TB}$ patients and $3612 \mathrm{~TB}$ free residents. The systematic random sampling technique was used to select TB patients from the selected governmental health facilities. Ethiopia adopts the tree health tier system; primary level health care (including the health center and district hospital and expected to serve up to 100,000 population), secondary level health care (includes the general hospital and expected to serve up to 1.5 million population) and the tertiary level health care (includes the specialized referral hospitals and expected to serve up to 5 million people). TB free residents were selected randomly from the community from the nearby house of the TB patients. The data were collected from July 2015-May 2018.

The data were collected using patient interview, measuring anthropometric indicators and collecting the stool and blood samples. The stool samples were collected to adjust for the effect of intestinal parasites on nutritional status because, in resource-limited settings like Ethiopia, intestinal parasites are the main predictor's malnutrition. The blood samples were collected to see the effect of anemia on underweight because literature reports their relationship. For the patient interview part, the questionnaire was prepared in English then translated to Amharic (local language) then back to English to keep its consistency. The interview was conducted by 30 diploma nurse professionals and supervised by 8 degree holder health professionals. Weight and height of each study participant were measured by clinical nurses. Digital weight scale was used to measure the weight of each study participant and weight was measured to the nearest $0.1 \mathrm{~kg}$. Height was measured using the vertical measuring rod to the nearest $0.1 \mathrm{~cm}$. The participants' shoes, hair clips, and braids were removed during the measurement. Participants were positioned feet together, feet flat on the ground, heels touching the backplate of the measuring instrument, legs straight, buttocks against the backboard, scapula against the backboard and arms were loosely at their side $[1,35]$.

The blood and stool samples were collected by 13degree holder laboratory technologists and supervised by second-degree holder laboratory technologists. For each study participant, one gram stool sample was collected in $10 \mathrm{ml} \mathrm{SAF}$ (sodium acetate-acetic acid-formalin solution) and transported with a preservative to the regional laboratory. A concentration technique was used. The stool samples were well mixed and filtered using a funnel with gauze, then centrifuged for one minute at 2000 RPM (revolution per minute) and the supernatant was discarded. 7 ML (Milliliter) normal saline was added, mixed with a wooden stick, $3 \mathrm{ML}$ ether was added and mixed well then centrifuged for $5 \mathrm{~min}$ at $2000 \mathrm{RPM}$. Finally, the supernatant was discarded and the whole sediment was examined for parasites. $5 \mathrm{ML}$ blood sample was collected from a study participant following standard operating procedures to measure the hemoglobin concentration and the red cell indices of patients using Mindray hematology analyzer [36]. CAGE tool was used to assess the problematic alcohol use. Study participants unable to read and wrote were labeled as illiterate.

To maintain the quality of the data pretest was conducted, training was given for data collectors and supervisors. The whole data collection processes were closely supervised by the investigators and supervisors.

The data were entered in the computer using Epi-info software transferred into SPSS software version 20 and WHO Anthro-plus software for the analysis. Descriptive statistics were used to identify the proportion of malnutrition. Binary logistic regression was used to identify the determinants of malnutrition. Variables with a $p$-value 
less than 0.05 were declared as predictors of malnutrition. Body mass index (BMI) was used to assess nutritional status. BMI was computed as $=$ weight (in kilogram)/ (height in meter) ${ }^{2}$. BMI less than $18.5 \mathrm{KG}$ / $\mathrm{M}^{2}$ was considered underweight [1].

Ethical clearance was obtained from the University of Bahir Dar ethical review committee. Formal permission was obtained from the Amhara National Regional State Health Bureau ethics committee and the respective authorities. Written informed consent was obtained from each study participant. The confidentiality of the data was kept at all steps. Study participants the right to withdraw from the study at any points were respected. Study participants with intestinal parasites or low hemoglobin concentration were linked to the nearby health facility.

\section{Results}

A total of 5045 study participants was included giving for the response rate of $93.1 \%, 286$ study participants did not volunteer to participate and 87 study participants were excluded due to incomplete data. The mean age of the study participants was 28 years (standard deviation [SD] \pm 14 years), 18 year was the youngest age of study participants, 1681 of the study participants was TB patients and 3364 of the study participants were TB free residents. Female constitute $53.9 \%$ (2721) of the study participants, $26 \%$ of the study participants were from the urban area, $90 \%$ of the study participants were Amhara by ethnicity and $96.7 \%$ of the study participants were Orthodox Christian believers.

\section{Profile of TB patients}

A total of $1681 \mathrm{~TB}$ patients were included giving for the response rate of $93 \%$. The mean age of the study participants was 27.78 years ( $\mathrm{SD} \pm 13.98$ years), $42.3 \%$ of TB patients were from the urban area and $76.8 \%$ of $\mathrm{TB}$ patients were pulmonary TB patients (Table 1 ).

The prevalence of underweight among TB patients was $57.17 \%$ (95\% CI: $54.80-59.54 \%$ ), $88.52 \%$ of TB patients were anemic (95\% CI: 86.99 - 90.04\%) and 48.25\% (718) of anemia was iron deficiency anemia (Table 2).

After adjusting for type of tuberculosis, sex, residence, educational status, intestinal parasitic infection, alcohol intake, age, HIV infection, family size, belief in avoiding a certain type of foods, income, smoking, and occupation; the following results were obtained: The odds of malnutrition among extra-pulmonary $\mathrm{TB}$ patients were 47\% higher than pulmonary $\mathrm{TB}$ patients (AOR 0.68: [95\% CI; 0.49-0.94]. In female TB patients, the odds of malnutrition were 2.56 higher than male. (AOR: 0.39 [95\% CI; 0.25-0.56]). The odds of malnutrition among TB patients were 3.84 folds higher in the urban areas than the rural area (AOR 3.84 [95\% CI: 2.74-5.54]). The odds of malnutrition were seven-folds higher among intestinal parasites positive TB patients than intestinal parasite negative TB patients (AOR 7: [95\% CI: 5.29.95]). Problematic alcohol use increases the odds of malnutrition by 1.52 folds (AOR 1.52: [95\% CI: 1.172.13]). Anemic TB patients had 3.23 folds higher risk of malnutrition than non-anemic TB patients (AOR 3.23: [95\% CI; 1.89-5.51]). The odds of malnutrition were 3.23 higher in TB patients whose age was greater than 25 years (AOR 0.31 [95\% CI; 0.21-0.46]). The odds of malnutrition were 1.96 folds higher among HIV positive TB patients than HIV negative TB patients (AOR 1.96: [95\% CI; 1.47-2.7]). The odds of malnutrition were 15.75 folds higher among TB patients with high family size (AOR 15.75: [95\% CI; 11.58-21.42]). Believe in avoiding certain types of food increase the odds of malnutrition by 3.19 folds (AOR 3.19: [95\% CI: 2.37-4.31]). (Table 3).

\section{Profile of TB free study participants}

A total of 3364 TB free study participants was included giving for the response rate of $93.13 \%$. The mean age of the study participants was 28.3 years (SD \pm 14.03 years). Female constitute $65.5 \%$ of the study participants, and $81.8 \%$ of the study participants were from the rural areas (Table 4).

\section{Malnutrition in the TB free residents}

The prevalence of malnutrition (underweight) among TB free residents was $23.37 \%$ (95\% CI: 21.93-24.80). The prevalence of anemia was $51.78 \%$ (95\% CI: $50.09-53.47 \%$ ). The predominant type of anemia was Normochromic Normocytic accounting for $63.32 \%$, followed by Hypochromic Microcytic anemia 32.72\%. (Table 5).

After adjusting for sex, residence, educational status, intestinal parasitic infection, alcohol intake, age, HIV infection, family size, believes in avoiding a certain type of food, income, smoking, and occupation; the following results were obtained:

The odds of malnutrition were 2.5 folds higher in male than female (AOR 2.5: [95\% CI; 1.72-3.63]). Intestinal parasitic infection increases the odds of malnutrition by 3 folds higher (AOR 3.07: [95\% CI; 2.38-3.96]). The odds of malnutrition were 7.82 folds higher among anemic residents (AOR 7.82: [95\% CI; 5.74-10.63]) than non-anemic residents. The odds of malnutrition among study participants whose age was $\geq 25$ years was $27 \%$ lower (AOR 0.73 [95\% CI; 0.59-0.91]). HIV infection increases the odds of malnutrition by 4.51 folds than HIV free residents (AOR 4.5:1 [95\% CI; 2.13-9.53]). (Table 6).

\section{Discussion}

The prevalence of underweight among $\mathrm{TB}$ patients was $57.17 \%$; the prevalence of underweight among $\mathrm{TB}$ free 
Table 1 Profile of TB patients $(n=1681)$

\begin{tabular}{|c|c|c|c|c|c|c|c|c|}
\hline \multirow{2}{*}{$S^{a}$} & \multirow[t]{2}{*}{ Population profile } & & \multirow[t]{2}{*}{ Frequency } & \multirow[t]{2}{*}{ Percentage } & \multicolumn{2}{|c|}{ Normal BMI } & \multicolumn{2}{|c|}{ Underweight } \\
\hline & & & & & Frequency & Percentage & Frequency & Percentage \\
\hline \multirow[t]{2}{*}{1.} & Sex & Male & 1162 & 69.1 & 527 & 31.4 & 633 & 37.8 \\
\hline & & Female & 519 & 30.9 & 193 & 11.3 & 327 & 19.4 \\
\hline \multirow[t]{2}{*}{2.} & Residence & Urban & 711 & 42.3 & 218 & 13 & 493 & 29.3 \\
\hline & & Rural & 970 & 57.7 & 502 & 29.9 & 468 & 27.8 \\
\hline \multirow[t]{2}{*}{3.} & Site of infection & $\begin{array}{l}\text { Pulmonary } \\
\text { tuberculosis }\end{array}$ & 1297 & 76.8 & 556 & 33.1 & 735 & 43.7 \\
\hline & & Extra-pulmonary TB & 390 & 23.2 & 164 & 9.8 & 226 & 13.4 \\
\hline \multirow[t]{2}{*}{4.} & HIV status & Positive & 595 & 35.2 & 307 & 18.3 & 285 & 17 \\
\hline & & Negative & 1089 & 64.8 & 339 & 20.2 & 676 & 40.2 \\
\hline \multirow[t]{3}{*}{5.} & Income in birr ${ }^{b}$ & $<1000$ & 1170 & 69.6 & 463 & 27.5 & 707 & 42.1 \\
\hline & & 1000-2000 & 316 & 18.8 & 186 & 11.1 & 130 & 7.7 \\
\hline & & $\geq 2001$ & 195 & 11.6 & 71 & 4.2 & 124 & 7.4 \\
\hline \multirow[t]{2}{*}{6.} & Occupation & Farmer & 835 & 49.7 & 407 & 24.2 & 428 & 25.5 \\
\hline & & Others & 846 & 50.3 & 313 & 18.6 & 533 & 31.7 \\
\hline \multirow[t]{2}{*}{7.} & Family size & $\leq 4$ & 648 & 38.5 & 499 & 29.7 & 149 & 8.9 \\
\hline & & $>4$ & 1033 & 61.5 & 221 & 13.1 & 812 & 48.3 \\
\hline \multirow[t]{4}{*}{8.} & Marital status & Single & 694 & 41.3 & 278 & 16.5 & 416 & 24.7 \\
\hline & & Married & 966 & 57.5 & 427 & 25.4 & 539 & 32.1 \\
\hline & & Divorced & 18 & 1.1 & 14 & 0.8 & 4 & 0.2 \\
\hline & & Widowed & 3 & 0.2 & 1 & 0.1 & 2 & 0.1 \\
\hline \multirow[t]{2}{*}{9.} & Anemia & Present & 1488 & 88.5 & 654 & 38.9 & 834 & 49.6 \\
\hline & & Absent & 193 & 11.5 & 66 & 3.9 & 127 & 7.6 \\
\hline \multirow[t]{2}{*}{10.} & Age & $<25$ & 1350 & 80.3 & 513 & 30.5 & 837 & 49.8 \\
\hline & & $\geq 25$ & 331 & 19.7 & 207 & 12.3 & 124 & 7.4 \\
\hline \multirow[t]{5}{*}{11.} & $\begin{array}{l}\text { Intestinal parasitic } \\
\text { infection }\end{array}$ & $\begin{array}{l}\text { Ascaris } \\
\text { lumbricoides }\end{array}$ & 409 & 24.3 & 82 & 4.9 & 327 & 19.5 \\
\hline & & Hookworm & 282 & 16.8 & 112 & 6.7 & 170 & 10.1 \\
\hline & & $\begin{array}{l}\text { Strongloid } \\
\text { stercolaris }\end{array}$ & 75 & 4.5 & 19 & 1.1 & 56 & 3.3 \\
\hline & & Others & 127 & 7.6 & 22 & 1.3 & 105 & 6.2 \\
\hline & & Not infected & 788 & 46.9 & 485 & 28.9 & 303 & 18 \\
\hline
\end{tabular}

${ }^{\mathrm{a}} \mathrm{SN}$ serial number

$\mathrm{b}_{1}$ US dollar $=23 \mathrm{birr}$

Table 2 The type of anemia among TB patients $(n=1488)$

\begin{tabular}{|c|c|c|c|c|c|c|c|c|c|c|}
\hline & & & \multicolumn{3}{|c|}{ Mean corpuscular volume (MCV) } & \multirow{3}{*}{$\begin{array}{l}\text { Total } \\
\text { No. }\end{array}$} & \multicolumn{4}{|l|}{ Malnutrition } \\
\hline & & & \multirow[t]{2}{*}{ Normocytic } & \multirow[t]{2}{*}{ Microcytic } & \multirow[t]{2}{*}{ Macrocytic } & & \multicolumn{2}{|l|}{ Norma } & \multicolumn{2}{|c|}{ Underweight } \\
\hline & & & & & & & Frequency & Percentage & Frequency & Percentage \\
\hline \multirow{5}{*}{$\begin{array}{l}\text { Mean corpuscular } \\
\text { hemoglobin } \\
\text { concentration (MCHC) }\end{array}$} & \multicolumn{2}{|c|}{ Normochromic } & 672 & 15 & 6 & 693 & 282 & 19 & 411 & 27.6 \\
\hline & \multicolumn{2}{|c|}{ Hypochromic } & 15 & 718 & 4 & 737 & 353 & 23.7 & 384 & 25.8 \\
\hline & \multicolumn{2}{|c|}{ Hyperchromic } & 14 & 12 & 32 & 58 & 19 & 1.3 & 39 & 2.6 \\
\hline & \multirow[t]{2}{*}{ Total } & No. & 701 & 745 & 42 & 1488 & & & & \\
\hline & & $\%$ & 47.11 & 50.07 & 2.82 & 100 & & & & \\
\hline
\end{tabular}


Table 3 Malnutrition predictors in TB patients $(n=1681)$

\begin{tabular}{|c|c|c|c|c|c|c|}
\hline \multirow[t]{2}{*}{ Variables } & & \multicolumn{2}{|l|}{ Malnutrition } & \multirow[t]{2}{*}{$\operatorname{COR}^{a}[95 \% \mathrm{Cl}]$} & \multirow[t]{2}{*}{$\mathrm{AOR}^{\mathrm{b}}[95 \% \mathrm{Cl}]$} & \multirow[t]{2}{*}{$P$-value } \\
\hline & & Underweight & Normal BMI & & & \\
\hline \multirow[t]{2}{*}{ Type of TB } & Pulmonary TB & 735 & 556 & $0.96[0.76-1.21]$ & $0.68[0.49-0.94]$ & 0.02 \\
\hline & Extra-pulmonary TB & 226 & 164 & Reference & Reference & \\
\hline \multirow[t]{2}{*}{ Sex } & Male & 635 & 527 & $0.71[0.58-0.88]$ & $0.39[0.25-0.56]$ & $<0.01$ \\
\hline & Female & 326 & 193 & Reference & Reference & \\
\hline \multirow[t]{2}{*}{ Residence } & Urban & 493 & 218 & 2.43 [1.98-2.98] & 3.84 [2.74-5.54] & $<0.01$ \\
\hline & Rural & 468 & 502 & Reference & Reference & \\
\hline \multirow[t]{2}{*}{ Educational status } & Literate & 756 & 544 & $1.19[0.95-1.5]$ & $0.72[0.52-1.02]$ & 0.06 \\
\hline & Illiterate & 205 & 176 & Reference & Reference & \\
\hline \multirow{2}{*}{$\begin{array}{l}\text { Intestinal parasitic } \\
\text { infection }\end{array}$} & Present & 658 & 235 & $4.48[3.64-5.51]$ & 7 [5.2-9.95] & $<0.01$ \\
\hline & Absent & 303 & 485 & Reference & Reference & \\
\hline \multirow[t]{2}{*}{ Alcohol intake } & Yes & 430 & 277 & 1.29 [1.06-1.58] & $1.52[1.17-2.13]$ & $<0.01$ \\
\hline & No & 531 & 443 & Reference & Reference & \\
\hline \multirow[t]{2}{*}{ Anemia } & Present & 834 & 654 & $0.66[0.48-0.91]$ & $3.23[1.89-5.51]$ & $<0.01$ \\
\hline & Absent & 127 & 66 & & & \\
\hline \multirow[t]{2}{*}{ Age } & $\geq 25$ & 124 & 207 & $0.37[0.29-0.47]$ & $0.31[0.21-0.46]$ & $<0.01$ \\
\hline & $<25$ & 837 & 513 & Reference & Reference & \\
\hline \multirow[t]{2}{*}{ HIV infection } & Positive & 285 & 307 & $0.57[0.46-0.70]$ & $1.96[1.47-2.7]$ & $<0.01$ \\
\hline & Negative & 676 & 413 & & & \\
\hline \multirow[t]{2}{*}{ Family size } & $>4$ & 812 & 221 & 12.30 [9.65-15.69] & 15.75 [11.58-21.42] & $<0.01$ \\
\hline & $\leq 4$ & 149 & 499 & & & \\
\hline \multirow{2}{*}{$\begin{array}{l}\text { Believe in avoiding a } \\
\text { certain type of food }\end{array}$} & Yes & 588 & 209 & $3.85[3.13-4.74]$ & $3.19[2.37-4.31]$ & $<0.01$ \\
\hline & No & 373 & 511 & & & \\
\hline
\end{tabular}

${ }^{\mathrm{a}} \mathrm{COR}$ crude odds ratio

${ }^{\mathrm{b}} \mathrm{AOR}$ adjusted odds ratio

residents was $23.37 \%$. This proportion was statistically significant $\left(\mathrm{X}^{2} 565.8, P\right.$-value $\left.<0.01\right)$. This finding indicates that $33.8 \%$ of excess malnutrition was observed as a result of TB. This is because TB infection increases the anabolic process and consumes additional energy [37], additionally, TB infection manifests with a reduction in appetite, nutrient malabsorption, finally increasing the risk of underweight [34].

The prevalence of anemia among TB patients was 88.52\%; the prevalence of anemia among ТВ free residents was $51.78 \%$. TB patients had a $36.74 \%$ excess burden of anemia as compared to the residents. This result was statistically significant at $\mathrm{X}^{2} 656.7 p$-value $<0.01$. This is due to the effect of TB on red blood cell production like decreasing the erythrocyte lifespan, poor erythrocyte iron incorporation, and decreased sensitivity to our supply of erythropoietin [38].

The odds of malnutrition among extra-pulmonary TB patients were $47 \%$ higher than pulmonary TB patients. This finding was in line with finding from Nepal [39]. This is due to the reason that the diagnosis of extrapulmonary TB is not easy as compared to pulmonary TB and patients were not early detected for the intervention
[40]. The odds of malnutrition were 2.5 times higher in female TB patients than male TB patients. This finding agrees with finding from Ghana [20]. This is due to the reason that the severity of $\mathrm{TB}$ was more virulent in female [41]. Additionally, Male could have better access to food compared to the female who might need to prioritize their families, especially their children.

The odds of malnutrition among TB patients were 3.84 folds higher in the urban areas than the rural. This finding disagrees with finding from India [42]. This is due to the reason that most urban residents in Ethiopia were living in the overcrowded condition [43].

The odds of malnutrition were 7 folds higher among intestinal parasites infected TB patients than intestinal free TB patients. This finding agrees with finding from Butajira [44]. This is because intestinal parasites decrease the food intake, interfere with the absorption of nutrients and they share the host nutrients [45].

TB patients with problematic alcohol use had 1.52 fold higher risk of becoming malnourished than nonalcoholic TB patients. This finding agrees with research finding from Tanzania [46]. This is due to the reason 
Table 4 Profile of TB free study participants $(n=3364)$

\begin{tabular}{|c|c|c|c|c|c|c|c|c|}
\hline \multirow[t]{2}{*}{ SN } & \multirow[t]{2}{*}{ Population profile } & & \multirow[t]{2}{*}{ Frequency } & \multirow[t]{2}{*}{ Percentage } & \multicolumn{2}{|l|}{ Normal BMI } & \multicolumn{2}{|c|}{ Underweight } \\
\hline & & & & & Frequency & Percentage & Frequency & Percentage \\
\hline \multirow[t]{2}{*}{1.} & Sex & Male & 1162 & 34.5 & 851 & 25.3 & 331 & 9.2 \\
\hline & & Female & 2202 & 65.5 & 1727 & 51.3 & 475 & 14.1 \\
\hline \multirow[t]{2}{*}{2.} & Residence & Urban & 611 & 18.2 & 451 & 13.4 & 160 & 4.8 \\
\hline & & Rural & 2753 & 81.8 & 2127 & 63.2 & 626 & 18.6 \\
\hline \multirow[t]{2}{*}{3.} & HIV status & Positive & 31 & 0.9 & 15 & 0.4 & 16 & 0.5 \\
\hline & & Negative & 3333 & 99.1 & 2563 & 76.2 & 770 & 22.9 \\
\hline \multirow[t]{3}{*}{4.} & Income in birr & $<1000$ & 2558 & 76 & 2000 & 59.5 & 558 & 16.6 \\
\hline & & 1000-2000 & 316 & 9.4 & 227 & 6.7 & 89 & 2.6 \\
\hline & & $\geq 2001$ & 490 & 14.56 & 351 & 10.43 & 139 & 4.13 \\
\hline \multirow[t]{2}{*}{5.} & Occupation & Farmer & 507 & 15.1 & 401 & 11.9 & 106 & 3.2 \\
\hline & & Others & 2857 & 84.9 & 2177 & 64.7 & 680 & 20.2 \\
\hline \multirow[t]{2}{*}{6.} & Smoking & Yes & 140 & 4.16 & 119 & 3.5 & 21 & 0.6 \\
\hline & & No & 3224 & 95.84 & 2459 & 73.1 & 765 & 22.7 \\
\hline \multirow[t]{2}{*}{7.} & Family size & $\leq 4$ & 151 & 4.5 & 115 & 3.4 & 36 & 1.1 \\
\hline & & $>4$ & 3243 & 95.5 & 2463 & 73.2 & 750 & 22.3 \\
\hline \multirow[t]{4}{*}{8.} & Marital status & Single & 1474 & 43.8 & 1169 & 34.8 & 305 & 9.1 \\
\hline & & Married & 1854 & 55.1 & 1379 & 41 & 475 & 14.1 \\
\hline & & Divorced & 33 & 1 & 27 & 0.8 & 6 & 0.2 \\
\hline & & Widowed & 3 & 0.1 & 3 & 0.1 & 0 & 0 \\
\hline \multirow[t]{2}{*}{9.} & Anemia & Present & 1742 & 51.8 & 1475 & 43.8 & 267 & 7.9 \\
\hline & & Absent & 1642 & 48.2 & 1103 & 32.8 & 519 & 15.4 \\
\hline \multirow[t]{2}{*}{10.} & Age in years & $<25$ & 2622 & 77.9 & 1984 & 59 & 638 & 19 \\
\hline & & $\geq 25$ & 742 & 22.1 & 594 & 17.7 & 148 & 4.4 \\
\hline \multirow[t]{5}{*}{11.} & Intestinal parasitic infection & Ascaris Lumbricoides & 530 & 15.8 & 331 & 9.8 & 199 & 5.9 \\
\hline & & Hookworm & 401 & 11.9 & 268 & 8 & 133 & 4 \\
\hline & & Strongyloides stercolaris & 99 & 2.9 & 74 & 2.2 & 25 & 0.7 \\
\hline & & Others & 433 & 12.9 & 319 & 9.5 & 114 & 2.7 \\
\hline & & Not infected & 1901 & 56.5 & 1586 & 47.1 & 315 & 9.4 \\
\hline
\end{tabular}

that alcoholic patients eat poorly, had poor digestion, storage, use, and excretion of nutrients [47].

The odds of malnutrition among anemic TB patients were 3.23 folds higher than non-anemic TB patients. This finding agrees with finding from Brazil [48]. This is due to the effect of red blood cells in the transportation of nutrients and minerals [49].
The odds of malnutrition were 3.23 folds higher among TB patients whose age was greater than 25 years. This finding agrees with finding from Ghana [33]. This is due to the reason that the risks of co-morbid illness like noncommunicable diseases were higher in old age [50].

The odds of malnutrition were 1.96 folds higher among HIV positive TB patients than HIV negative TB patients.

Table 5 The type of anemia among TB free residents $(n=1742)$

\begin{tabular}{|c|c|c|c|c|c|c|c|c|c|}
\hline & & \multicolumn{3}{|l|}{ MCV } & \multirow[t]{2}{*}{ Total } & \multicolumn{2}{|l|}{ Normal } & \multicolumn{2}{|c|}{ Underweight } \\
\hline & & Normocytic & Microcytic & Macrocytic & & Frequency & Percentage & Frequency & Percentage \\
\hline \multirow[t]{4}{*}{$\mathrm{MCHC}$} & Normochromic & 1103 & 11 & 6 & 1120 & 853 & 49 & 267 & 15.3 \\
\hline & Hypochromic & 2 & 570 & 4 & 576 & 576 & 33.1 & 0 & 0 \\
\hline & Hyperchromic & 2 & 12 & 32 & 46 & 46 & 2.6 & 0 & 0 \\
\hline & Total & 1107 & 293 & 42 & 1742 & & & & \\
\hline
\end{tabular}


Table 6 Predictors of malnutrition among TB free residents $(n=3364)$

\begin{tabular}{|c|c|c|c|c|c|c|}
\hline \multirow[t]{2}{*}{ Variables } & & \multicolumn{2}{|l|}{ Malnutrition } & \multirow[t]{2}{*}{ COR $[95 \% \mathrm{Cl}]$} & \multirow[t]{2}{*}{ AOR $[95 \% \mathrm{Cl}]$} & \multirow[t]{2}{*}{$P$-value } \\
\hline & & Underweight & Normal BMI & & & \\
\hline \multirow[t]{2}{*}{ Smoking } & Yes & 21 & 119 & $0.57[0.34-0.93]$ & 0.64 [0.39-1.05] & 0.076 \\
\hline & No & 765 & 2459 & & & \\
\hline \multirow[t]{2}{*}{ Sex } & Male & 311 & 851 & $1.33[1.12-1.57]$ & $2.5[1.72-3.63]$ & $<0.01$ \\
\hline & Female & 475 & 1727 & & & \\
\hline \multirow[t]{2}{*}{ Residence } & Urban & 160 & 451 & $1.21[0.98-1.48]$ & 0.89 [0.71-1.13] & 0.34 \\
\hline & Rural & 626 & 2127 & & & \\
\hline \multirow[t]{2}{*}{ Income } & $<2000$ birr & 734 & 2442 & $0.79[0.56-1.11]$ & $1.434[1.00-2.06]$ & 0.06 \\
\hline & $\geq 2000$ birr & 52 & 136 & & & \\
\hline \multirow[t]{2}{*}{ Intestinal parasitic infection } & Present & 471 & 992 & $2.39[2.02-2.82]$ & 3.07 [2.38-3.96] & $<0.01$ \\
\hline & Absent & 315 & 1586 & & & \\
\hline \multirow[t]{2}{*}{ Alcohol intake } & Yes & 251 & 878 & $0.91[0.76-1.08]$ & 1.07 [0.88-1.29] & 0.53 \\
\hline & No & 535 & 1700 & & & \\
\hline \multirow[t]{2}{*}{ Anemia } & Present & 267 & 1475 & $0.38[0.32-0.46]$ & $7.82[5.74-10.63]$ & $<0.01$ \\
\hline & Absent & 519 & 1103 & & & \\
\hline \multirow[t]{2}{*}{ Age } & $\geq 25$ & 148 & 594 & 0.77 [0.63-0.95] & 0.73 [0.59-0.91] & $<0.01$ \\
\hline & $<25$ & 638 & 1984 & & & \\
\hline \multirow[t]{2}{*}{ HIV infection } & Positive & 16 & 15 & $3.55[1.66-7.61]$ & 4.51 [2.13-9.53] & $<0.01$ \\
\hline & Negative & 770 & 2563 & & & \\
\hline \multirow[t]{2}{*}{ Family size } & $\leq 4$ & 36 & 115 & 1.03 [0.69-1.53] & $0.96[0.63-1.43]$ & 0.81 \\
\hline & $>4$ & 750 & 2463 & & & \\
\hline \multirow{2}{*}{$\begin{array}{l}\text { Believe in avoiding a } \\
\text { certain type of food }\end{array}$} & Yes & 447 & 1283 & 1.33 [1.13-1.57] & 0.87 [0.73-1.05] & 0.14 \\
\hline & No & 339 & 1295 & & & \\
\hline
\end{tabular}

This finding agrees with finding from Tanzania [46]. This is due to the reason that HIV positive patients were not economically productive so that they can't get the access to the different variety of foods [51], HIV positive patients have a poor appetite, poor absorption of nutrients $[52,53]$.

The odds of malnutrition were 15.75 folds higher among TB patients with family size greater than 4 . This finding agrees with finding from India [20]. This is because high family size decreases the household income leading to the low dietary intake of household members [54].

Believe in avoiding a certain type of foods (mostly animal products) increase the odds of malnutrition by 3.19 folds. This finding was in line with finding from Ghana [55]. This is due to the reason that patients will not take important nutrients due to their behavior of avoiding that type of food [56].

Family size and believe in avoiding a certain type of food were not the predictors of malnutrition among the tuberculosis-free residents, but these variables were the predictors of malnutrition among TB patients. These show that TB patients are very susceptible to malnutrition even the very distal reason for malnutrition in the community became a proximal reason for $\mathrm{TB}$ patients.

The limitation of the study might be related to the cross-sectional nature of the study, which makes difficult to find whether the exposure precedes the outcome. However, this limitation works only for modifiable variables thought time. Since we used patient interview methods, recall bias might occur, however, we included only newly diagnosed TB patients which significantly drop the recall bias.

\section{Conclusion}

A very high proportion of TB patients were malnourished. TB patients were highly susceptible to malnutrition and even a very distal factor for malnutrition became proximal for TB patients. The nutritional status of TB patients was affected by the site of infection, sex, residence, intestinal parasite infection, alcohol.

\section{Recommendation}

The DOTS for TB intervention should consider incorporating more nutritional support for the patients. Because a 
significant proportion of TB patients were malnourished, they can't afford access to nutritionally rich foods and administering the anti-TB drugs alone will decrease the treatment success rate. Also, the guideline should consider iron supplementation and deworming as part of the TB treatment.

\section{Abbreviations}

AOR: Adjusted odds ratio; BMI: Body Mass Index; Cl: Confidence Interval; COR: crude odds ratio; DOTS: Directly Observed Treatment Strategy; H.nana: Hemnolephus Nana; HC: Health Center; IT: Information Technology; MCHC: Mean corpuscular hemoglobin concentration; MCV: Mean corpuscular volume; MDR-TB: Multidrug Resistance Tuberculosis; ML: Milliliters; OPD: Out Patient Department; OR: Odds Ratio; RPM: Revolution per Minute; SAF: Sodium Acetate Acetic Acid Formulation; SD: Standard Deviation; SPSS: Statistical Software for Social Science; TB: TB; USA: United State of America; WHO: World Health Organization

\section{Acknowledgments}

We would like to acknowledge the Amhara National Regional State Health Bureau for their unreserved efforts during the data collection process. We would also like to acknowledge the patient families for their good cooperation during the data collection phase. At last, but not least we would like to extend our gratitude to all organizations and people that support this research work.

\section{Authors' contributions}

BEF and TEF conceived the experiment; BEF, FB, and TEF performed the experiment, plan the data collection process, analyzed and interpreted the data. BEF, FB, and TEF wrote the manuscript and approved the final draft for publication.

\section{Funding}

This research work was financially supported by Bahir Dar University. The funder has no role in design of the study and collection, analysis, and interpretation of data and in writing the manuscript.

\section{Availability of data and materials}

The datasets used and/or analyzed during the current study are available from the corresponding author on reasonable request.

\section{Ethics approval and consent to participate}

Ethical clearance was obtained from the Bahir Dar University ethical review committee. Permission to conduct the study was also obtained from the Amhara national regional state health bureau. Written consent was obtained from each patient.

\section{Consent for publication}

Not applicable.

\section{Competing interests}

The authors declare that they have no competing interests.

\section{Author details}

${ }^{1}$ Department of Epidemiology and Biostatistics, University of Bahir Dar, Bahir Dar, Ethiopia. ${ }^{2}$ Department of pediatrics, University of St Paul, Addis Ababa, Ethiopia. ${ }^{3}$ Department of medical laboratory sciences, University of Bahir Dar, Bahir Dar, Ethiopia.

\section{Received: 6 June 2019 Accepted: 30 September 2019}

Published online: 21 October 2019

\section{References}

1. NHANES: Anthropometric procedure manuals vol. 1. Uinited state of amercia: national health and nutrtiona examination survey; 2007.

2. WHO. nutritional landscape information system. Geneva: World Health Organization; 2010. p. 1-51.

3. Bernstein M, Munoz N. Nutrition for the older adult: Jones \& Bartlett Learning; 2019.
4. Kumar R, Abbas F, Mahmood T, Somrongthong R. Prevalence and factors associated with underweight children: a population-based subnational analysis from Pakistan. BMJ Open. 2019;9(7):e028972.

5. WHO. Global Tuberculosis Report 2018. Swetherland: World Health Organization; 2018. p. 277.

6. Cegielski J, McMurray D. The relationship between malnutrition and tuberculosis: evidence from studies in humans and experimental animals. Int J Tuberc Lung Dis. 2004;8(3):286-98.

7. Bhargava A, Oxlade O, Menzies D. Undernutrition and the incidence of tuberculosis in India: national and subnational estimates of the population attributable fraction related to undernutrition. Natl Med J India. 2014;27:4-9.

8. Schaible U, Kaufmann S. Malnutrition and infection: complex mechanisms and global impacts. PLoS Med. 2007;4:e115.

9. Leyton G, Camb M. Effects of slow starvation. Lancet. 1946;20:73-9.

10. Chan J, Tanaka K, Tsang M. Effects of protein calorie malnutrition on tuberculosis mice. Microbiology. 1996;93:14857-61.

11. Pakasi T, Karyadi E, Dolmans W, vanderMeer J, vanderVelden K. Malnutrition and socio-demographic factors associated with pulmonary tuberculosis in Timor and Rote Islands, Indonesia. Int J Tuberc Lung Dis. 2009;13(6):755-9.

12. WHO. nutrtional care and support for patient care with tuberculosis In. Edited by organization. Geneva: WH; 2013.

13. Peggy $P$, Luis $O$, Ellen $P$. Nutrition and tuberculosis, a review of litratures and consideration for tuberculosis contrle program In. Edited by Oluwole D, Duale S, Opoku J, Allen W, Musau S, Waisbord S, vol. 1. USA: USAID; 2010. p. 55.

14. Zachariah R, Spiehnann M, Harries A, Salanipon F. Moderate to severe malnutrition in patients with tuberculosis is a risk factor associated with early death. Trans R Soc Trop Med Hyg. 2002;96:291-4.

15. Kim H, Lee C, Shin S, Lee J, Kim Y, Chung H, Han S, Shim Y, Kim D. The impact of nutritional defi cit on mortality of in-patients with pulmonary tuberculosis. Int J Tuberc Lung Dis. 2009;14(1):79-85.

16. Khan A, Sterling T, Reves R, Vernon A, Horsburgh C. Lack of weight gain and relapse risk in a large tuberculosis treatment trial. Am J Respir Crit Care Med. 2006;174:344-8.

17. Khan A. Lack of weight gain and relapse risk in a large tuberculosis treatment trial. Am J Respir Crit Care Med. 2006;174:344-8.

18. Onwubalili J. Malnutrition among tuberculosis patients in Harrow, England. Eur J Clin Nutr. 1988;42(4):363-6.

19. Surya K, Harshita G, Savita A. Significance of nutrition in pulmonary tuberculosis. Food Sci Nutr. 2015;55(7):955-63.

20. Amit K, Rakesh K, Kandpal S, Girish S. Nutritional status in multi-drug resistance-pulmonary tuberculosis patients. Indian J Community Health. 2014;26(02):204-9.

21. Kennedy N, Ramsay A, Uiso L, Gutmann J, Ngowi F, Gillespie S. Nutritional status and weight gain in patients with pulmonary tuberculosis in Tanzania. Trans R Soc Trop Med Hyg. 1996;90:162-6.

22. Chávez P, Blank R, Smith F, Bayona J, Becerra M, Nick C. Identifying early treatment failure on category I therapy for pulmonary tuberculosis in Lima ciudad, Peru. Int J Tuberc Lung Dis. 2004;8:52-8.

23. Ramachandran G, Hemanth K, Bhavani P, Poorana G, Sekar L, Vijayasekaran D, Banu R, Ramesh K, Ravichandran N, Mathevan G, et al. Age, nutritional status and INH acetylator status affect pharmacokinetics of anti-tuberculosis drugs in children. Int J Tuberc Lung Dis. 2013;17(6):800-6.

24. VanLettow M, Kumwenda J, Harries A, Whalen C, Taha T, Kumwenda N, Kang'ombe C, Semba R. Malnutrition and the severity of lung disease in adults with pulmonary tuberculosis in Malawi. Int J Tuberc Lung Dis. 2003; 8(2):211-7.

25. Abba K, Sudarsanam T, Grobler L, Volmink J: Nutritional supplements for people being treated for active tuberculosis. In. Edited by Rev CDS; 2008.

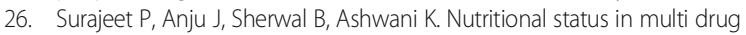
resistance-pulmonary tuberculosis patients. Int J Pharm Bio Sci. 2010;1(2):1-5.

27. Paton N, Chua Y, Earnest A, Chee C. Randomized controlled trial of nutritional supplementation in patients with newly diagnosed tuberculosis and wasting. Am J Clin Nutr. 2004;80(2):460-5.

28. Silvana P, Maria C, Florisneide B, Susan P. Prevalence of nutritional deficiency in patients with pulmonary tuberculosis. J Bras Pneumol. 2013; 39(4):476-83.

29. Krapp F, Véliz J, Cornejo E, Gotuzzo E, Seas C. Bodyweight gain to predict treatment outcome in patients with pulmonary tuberculosis in Peru. Int J Tuberc Lung Dis. 2008;12(10):1153-9.

30. Monique L, Anthony H, Johnny K, Ed Z, Tamara C, Taha T, Richard S. Micronutrient malnutrition and wasting in adults with pulmonary 
tuberculosis with and without HIV co-infection in Malawi. BMC Infect Dis. 2004:4(61):1-8.

31. Henrik F, Nyagosya R, Marianne P, Christian M, John C, Henrik K, Pascal M, Christian S, Andersen A. Hypovitaminosis D is common among pulmonary tuberculosis patients in Tanzania but is not explained by the acute phase response. J Nutr. 2008;138:2474-80.

32. Dodor E. Evaluation of nutritional status of new tuberculosis patients at the Eff a-Nkwanta regional hospital. Ghana Med J. 2008;42:22-4.

33. DODOR E. Evaluation of nutrtional status of new tuberculosis patients at the effia-kwa taregio regional hospital. Ghana Med J. 2008;42(1):22-9.

34. Gupta KB, Gupta R, Atreja A, Verma M, Vishvkarma S. Tuberculosis and nutrition. Lung India. 2009;26(1):9.

35. WHO: Measuring Length/Height and Weight. Switzerland, Geneva world health organization department of nutrition health and development 2008.

36. Institute $\mathrm{S}$. Methods in Parasitology. In: Sodium acetate-acetic acid-formalin solution method for stool specimen. Basel: Swiss TPH: Swiss Tropical Institute; 2005. p. 1-18.

37. Schaible UE, Kaufmann SH. Malnutrition and infection: complex mechanisms and global impacts. PLoS Med. 2007;4(5):e115.

38. Davis SL, Littlewood TJ. The investigation and treatment of secondary anaemia. Blood Rev. 2012;26(2):65-71.

39. Sreeramareddy CT, Panduru KV, Verma SC, Joshi HS, Bates MN. Comparison of pulmonary and extrapulmonary tuberculosis in Nepal- a hospital-based retrospective study. BMC Infect Dis. 2008;8:8.

40. Purohit M, Mustafa T. Laboratory diagnosis of extra-pulmonary tuberculosis (EPTB) in resource-constrained setting: state of the art, challenges and the need. J Clin Diagn Res. 2015;9(4):EE01-6.

41. Ducomble T, Tolksdorf K, Karagiannis I, Hauer B, Brodhun B, Haas W, Fiebig $\mathrm{L}$. The burden of extrapulmonary and meningitis tuberculosis: an investigation of national surveillance data, Germany, 2002 to 2009. 2013.

42. Bhargava A, Chatterjee M, Jain Y, Chatterjee B, Kataria A, Bhargava M, Kataria R, D'Souza R, Jain R, Benedetti A. Nutritional status of adult patients with pulmonary tuberculosis in rural Central India and its association with mortality. PLoS One. 2013;8(10):e77979.

43. Rice J, Rice JS. The concentration of disadvantage and the rise of an urban penalty: urban slum prevalence and the social production of health inequalities in the developing countries. Int J Health Serv. 2009;39(4):749-70.

44. Gedle D, Gelaw B, Muluye D, Mesele M. Prevalence of malnutrition and its associated factors among adult people living with HIV/AIDS receiving antiretroviral therapy at Butajira hospital, southern Ethiopia. BMC Nutrition. 2015;1(1):5.

45. Harhay MO, Horton J, Olliaro PL. Epidemiology and control of human gastrointestinal parasites in children. Expert Rev Anti-Infect Ther. 2010;8(2): 219-34.

46. Friis $\mathrm{H}$, Range N, Braendgaard Kristensen C, Kaestel P, Changalucha J, Malenganisho W, Krarup H, Magnussen P, Bengaard Andersen A. Acute- phase response and iron status markers among pulmonary tuberculosis patients: a cross-sectional study in Mwanza, Tanzania. Br J Nutr. 2009;102(2):310-7.

47. Usha R, Sailesh KS, Divya D, MJ VK, Angel J, Mukkadan J. A study on comparison of random blood glucose levels in alcoholic and non-alcoholic males of Ernakulam district, Kerala. Asian J Health Sci. 2013;1(1).

48. Lins TB, Soares Ede M, dos Santos FM, Mandacaru PM, Pina T, de Araujo Filho JA. Mycobacterium tuberculosis and human immunodeficiency virus coinfection in a tertiary care hospital in Midwestern Brazil. Le infezioni in medicina. 2012;20(2):108-16.

49. Epstein E. Mineral nutrition of plants: mechanisms of uptake and transport. Annu Rev Plant Physiol. 1956;7(1):1-24.

50. Nunes HE, Goncalves EC, Vieira JA, Silva DA. Clustering of risk factors for non-communicable diseases among adolescents from southern Brazil. PLoS One. 2016;11(7):e0159037.

51. Onyeke AC. Effects of Hiv/Aids on the livelihoods of rural farmers in Enugu state, Nigeria; 2015.

52. Duggal S, Chugh TD, Duggal AK. HIV and malnutrition: effects on immune system. Clin Dev Immunol. 2012;2012:8.

53. Chandra RK, Kumari S. Nutrition and immunity: an overview. J Nutr. 1994; 124(8 Suppl):1433s-5s.

54. Magallanes JM. Human nutrition: the impact of family size and income on dietary intake. Philipp Sociol Rev. 1984;32(1/4):69-79.

55. Dodor E. Evaluation of nutritional status of new tuberculosis patients at the effia-nkwanta regional hospital. Ghana Med J. 2008;42(1):22-8.
56. Sutliffe JT, Fuhrman JH, Carnot MJ, Beetham RM, Peddy MS. Nutrient-dense, plant-rich dietary intervention effective at reducing cardiovascular disease risk factors for worksites: a pilot study. Altern Ther Health Med. 2016;22(5):32-6.

\section{Publisher's Note}

Springer Nature remains neutral with regard to jurisdictional claims in published maps and institutional affiliations.
Ready to submit your research? Choose BMC and benefit from:

- fast, convenient online submission

- thorough peer review by experienced researchers in your field

- rapid publication on acceptance

- support for research data, including large and complex data types

- gold Open Access which fosters wider collaboration and increased citations

- maximum visibility for your research: over $100 \mathrm{M}$ website views per year

At $\mathrm{BMC}$, research is always in progress.

Learn more biomedcentral.com/submissions 